\title{
Multidrug Resistant E. coli Isolated from Kadaknath Poultry Bird
}

\author{
Chhabra Daljeet*, R. Gangil, R. Sikrodia, S. Audarya and R. Sharda \\ Department of Veterinary Microbiology, College of Veterinary Sc. and A.H., \\ Mhow (M.P.), India \\ *Corresponding author
}

A B S T R A C T

\begin{tabular}{|l|}
\hline Ke y w o r d s \\
AST, \\
Antibiotics, \\
poultry
\end{tabular}

Keywords

AST,

Antibiotics,

Article Info

Accepted:

Available Online:

10 February 2020

\section{Introduction}

Kadaknath is an Indian breed of chicken local to Jhabua and Dhar districts. Extraintestinal infection with avian pathogenic Escherichia coli (APEC) induces colibacillosis in chickens. It is characterized by polyserositis, septicemic shock, and cellulitis and is responsible for enormous economic losses and frequent antibiotic treatment (Kim et al., 2007).

Antimicrobial therapy is an important tool in reducing both the incidence and mortality associated with avian colibacillosis. However, in poultry flocks, inappropriate antibiotic therapy and using antibiotics as growth promoters may result in high antibiotic selection pressure. Therefore, poultry pathogenic bacteria contain a relatively high proportion of resistant isolates.

These resistant bacteria cause problems in rearing poultry flocks and in human health.The antimicrobial use in the chicken is expected to rise by $129 \%$, by 2030 in the AsiaPacific region (Tonu et al., 2011).

The development of resistance is a complex process associated with the presence of resistance encoding genes that are found inside plasmids or chromosomal genetic material. Integrons are the genetic material responsible for capturing resistance genes that spread via the genetic mobile elements; transposons and plasmid (Geidam et al., 2012). 


\section{Materials and Methods}

The liver and heart samples were collected from chickens, suspected for colibacillosis on post mortem. The presumptive isolation of bacterial isolates as E. coli was accomplished by colonial and bacterial morphology. Further, identification of bacterial isolates was done by both traditional methods and readymade kits (Hi media).

Traditional biochemical tests were carried out as per procedure described by Barrow and Feltham (1993), Cheesbrough (1994) and Collee et al., (1996). Readymade Hi E. coli identification kits (Hi Media) were used for identification of isolates. All the E. coli isolates $(\mathrm{n}=10)$, were submitted to the disc diffusion test according to the as per the procedure described by Bauer et al., (1966). The interpretation of result was made in accordance with the instruction supplied by manufacture. Resistant to multiple antimicrobials was considered as MDR.

\section{Results and Discussion}

Antibiotic resistance has emerged as a major threat to public health in this century, as evident from global surveillance data. The indiscriminate and overuse of antibiotics are resulting in widespread antimicrobial resistance, which has received considerable National and International attention.

All the 10 isolates of $E$. coli were tested for in vitro sensitivity towards 9 antibacterial drugs. These 9 antibiotics belonged to the four groups viz. fluoroquinolones, aminoglycosides, cephalosporins and macrolids. Sensitivity of isolates to various drugs is summarized in Table 1.

Table.1 Percentage sensitivity of $E$. coli isolates to different antimicrobial agents

\begin{tabular}{|c|l|c|c|c|c|c|c|}
\hline \multirow{2}{*}{ S. No. } & \multicolumn{1}{|c|}{ Antibiotics } & \multicolumn{5}{|c|}{ Total no. of isolates (n=10) } \\
\cline { 3 - 8 } & & \multicolumn{2}{|c|}{ Sensitive } & \multicolumn{2}{c|}{ Intermediate } & \multicolumn{2}{c|}{ Resistant } \\
\hline & & No. & $\%$ & No. & $\%$ & No. & \% \\
\hline $\mathbf{1 .}$ & Azithromycin & 6 & 60 & 1 & 10 & 3 & 30 \\
\hline $\mathbf{2 .}$ & Cefuroxime & 0 & 00 & 9 & 90 & 1 & 10 \\
\hline $\mathbf{3 .}$ & Cephalothin & 0 & 00 & 0 & 00 & 10 & 100 \\
\hline $\mathbf{4 .}$ & Cefepime & 0 & 00 & 9 & 90 & 1 & 10 \\
\hline $\mathbf{5 .}$ & Erythromycin & 0 & 00 & 0 & 00 & 10 & 100 \\
\hline $\mathbf{6 .}$ & Enrofloxacin & 0 & 00 & 0 & 00 & 10 & 100 \\
\hline $\mathbf{7 .}$ & Kanamycin & 0 & 00 & 4 & 40 & 6 & 60 \\
\hline $\mathbf{8 .}$ & Moxifloxacin & 0 & 00 & 0 & 00 & 10 & 100 \\
\hline $\mathbf{9 .}$ & Norfloxacin & 0 & 00 & 0 & 00 & 10 & 100 \\
\hline
\end{tabular}


E. coli isolates showed variable percentages of sensitivity and resistance to the different antibiotics.The 100 percent resistance was found against 5 antibiotics Cephalothin, Erythromycin, Enrofloxacin, Moxifloxacin and Norfloxacin. The only drug showed sensitivity was Azithromycin (Table 1).

Various antibiotics used for AST in this study have also been reported by others viz. Miranda et al., (2008), Saberfar et al., (2008), Abera and Kibret (2014) and Sarba et al., (2019). However, variation in resistance and sensitivity percent has been found in various reports. Abera and Kibret (2014) reported $55 \%$ Azithromycin resistance level in E. coli which is higher than the findings of present study.

In our study, $100 \%$ E. coli isolates were resistant to Enrofloxacin as comparable to the findings of Kim et al., (2007) and Saberfar et al., (2008) who reported $71.3 \%$ and $76 \%$, resistance, respectively. Saberfar et al., (2008) also observed resistance levels as - $0 \%$ for Kanamycin and $\geq 99 \%$ for Erythromycin and the findings of Kanamycin are contrast to the present findings.

Kibret and Abera (2011) reported high resistance rate to Erythromycin $(89.4 \%)$ and high sensitivity rates to Norfloxacin $(90.6 \%)$. The resistivity patterns of $E$. coli strains are comparable but the findings of Norfloxacin do not collaborate with the present findings.

\section{Multi drug resistance}

It was noted that no antibiotic was $100 \%$ effective, with all the isolates (100\%) presenting multidrug - resistance. Multiple drug resistance to 4 to 7 antibacterial agents simultaneously was observed in all isolates (Table 2). The maximum (40\%) isolates were resistant to 4 or 7 drugs. None of the isolate was resistant to all the 9 antimicrobial agents.

Table.2 Multiple drug resistance in E. coli isolates.

\begin{tabular}{|r|c|c|c|}
\hline S. No. & No. of antibiotics & No. of resistant isolates & $\begin{array}{r}\text { Percent of resistant isolates } \\
(\mathbf{n = 1 0})\end{array}$ \\
\hline $\mathbf{1 .}$ & 7 & 4 & $40 \%$ \\
\hline $\mathbf{2 .}$ & 6 & 1 & $10 \%$ \\
\hline $\mathbf{3 .}$ & 5 & 1 & $10 \%$ \\
\hline $\mathbf{4 .}$ & 4 & 4 & $40 \%$ \\
\hline
\end{tabular}

All isolated $E$. coli showed resistance to 4 or more antibiotics, so multiple resistances was observed in all of our isolates. Multi drug resistance against was also reported by Manishimwe et al., (2017), Amer et al., (2018) and Subedi et al., (2018). The multidrug resistance's feature has been observed in $E$. coli samples from avian origin in Brazil and other American countries (Zanatta et al., 2004; Smith et al., 2007), as well as in Europe (Guerra et al., 2003), Asia (Sahoo et al., 2012), Africa (Ogunleye et al., 2008), etc. This fact demonstrates that the use of antimicrobials in poultry industry over the years has increasingly been favouring the emergence of resistant isolates. 
The global emergence of multidrug-resistant Gram-negative bacteria is a growing threat to antibiotic therapy. This can result from different reasons, including blind antimicrobial therapy, excessive usage of antimicrobials for prophylaxis, inappropriate treatment, and impaired quarantine systems.Antibiotic-resistant bacteria pose a severe challenge to both veterinary and health professionals because they have a negative impact on therapy. Hence, it is recommended that there should be judicious use of antibiotics.

\section{References}

Abera, B. and Kibret, M. (2014). Azithromycin, fluoroquinolone and chloramphenicol resistance of nonchlamydia conjunctival bacteria in rural community of Ethiopia. Indian $J$. Ophthalmol., 62(2): 236-239.

Amer, M.M., Mekky, H.M., Amer, A.M. and Fedawy, H.S. (2018). Antimicrobial resistance genes in pathogenic Escherichia coli isolated from diseased broiler chickens in Egypt and their relationship with the phenotypic resistance characteristics, Veterinary World, 11(8): 1082-1088.

Barrow, G.I. and Feltham, R.K.A. (1993). Cowan and Steel's manual for the identification of medical bacteria, $3^{\text {rd }}$ edn. Cambridge University Press, Cambridge. pp 140-143.

Bauer, A.W., Kirby, W.M.M., Sherris, J.S., and Turk,M. (1966). Antibiotic susceptibility testing by a standard single disc method. American Journal of clinical Pathology, 45: 493-496.

Cheesbrough, M. (1994). Medical Laboratory Manual for Tropical Countries. $1^{\text {st }}$ edn. Vol.II, E.L.B.S. and Butterworth and Co. Ltd., Kent. pp 401-404.

Collee, J.G., Fraser, A.G., Marion, B.P. and
Simmons, A. (1996). Mackie and McCartney's Practical Medical Microbiology, $4^{\text {th }}$ edn. Churchill Livingstone, New York.

Geidam, Y.A., Ambali, A.G. and Onyeyili, P.A. (2012). Detection and antibiotic sensitivity pattern of avian pathogenic Escherichia coli strains among rural chickens in the arid region of Northeastern Nigeria. Veterinary World, 5(6): 325-329.

Guerra, B., Junker, E., Schroeter, A., Malorny, B., Lehmann, S. and Helmuth, R. (2003). Phenotypic and genotypic characterization of antimicrobial resistance in German Escherichia coli isolates from cattle, swine and poultry. Journal of Antimicrobial Chemotherapy, 52(3):489-492.

Kibret, M. and Abera, B. (2011). Antimicrobial susceptibility patterns of $E$. coli from clinical sources in northeast Ethiopia. Afr. Health Sci., 11(Suppl 1): S40-S45.

Kim, T.E., Jeong, Y.W., Cho, S.H., Kim, S.J. and Kwon, H.J. (2007). Chronological study of antibiotic resistances and their relevant genes in Korean avian pathogenic Escherichia coli Isolates. Journal of Clinical Microbiology, 45(10): 3309-3315.

Manishimwe, R., Buhire, M., Uyisunze, A., Turikumwenayo, J.B. and Tukei, M. (2017). Characterization of antibiotic resistant Escherichia coli in different poultry farming systems in the Eastern Province and Kigali City of Rwanda. Revue D'elevage Et De Medecine Veterinaire Des Pays Tropicaux, 70(1): 13-19.

Miranda, J.M., Vázquez, B.I., Fente, C.A., Calo-Mata, P., Cepeda, A. and Franco, C.M. (2008). Comparison of antimicrobial resistance in Escherichia coli, Staphylococcus aureus and Listeria monocytogenes strains isolated 
from organic and conventional poultry meat. J. Food Prot., 71(12):2537-42.

Ogunleye, A.O., Oyekunle, M.A. and Sonibare, A.O. (2008). Multidrug resistant Escherichia coli isolates of poultry origin in Abeokuta, South Western Nigeria. Veterinarski Arhiv, 78(6): 501-509.

Saberfar, E., Pourakbari, B., Chabokdavan, and Taj Dolatshahi, F. (2008). Antimicrobial Susceptibility of Escherichia coli isolated from Iranian broiler chicken flocks, 2005-2006. The Journal of Applied Poultry Research, 17(2):302-304,

Sahoo, T.K., Sahoo, L., Sarangi, L.N. and Panda, K.N. (2012). Prevalence, isolation, characterisation and antibiogram study of pathogenic Escherichia coli from different poultry farms of Odisha. Journal of Advanced Veterinary Research, 2:169-172, 2012.

Sarba, E.J., Kelbesa, K.A., Bayu, M.D., Gebremedhin, E.Z., Borena, B.M. and Teshale, A. (2019). Identification and antimicrobial susceptibility profile of Escherichia coli isolated from backyard chicken in and around ambo, Central Ethiopia, BMC Vet. Res. 15: 85.

Sarker, M.S., Mannan, M.S., Ali, M.Y., Bayzid, M., Ahad, A. and Zamila Bueaza Bupasha, Z.B. (2019). Antibiotic resistance of Escherichia coli isolated from broilers sold at live bird markets in Chattogram, Bangladesh. J. Adv. Vet. Anim. Res., 6(3): 272-277.

Smith, J.L., Drum, D.J.V., Dai, Y., Kim, J. M., Sanchez, S. , Maurer, J. J., Hofacre, C. L. and Lee, M.D. (2007). Impact of antimicrobial usage on antimicrobial resistance in commensal Escherichia coli strains colonizing broiler chickens. Apllied and Environmental Microbiology, 73: 14041414.

Subedi, M., Luitel, H., Devkota, B., Bhattarai, R.K., Phuyal, S., Panthi, P., Shrestha, A. and Chaudhary, D.K. (2018). Antibiotic resistance pattern and virulence genes content in avian pathogenic Escherichia coli (APEC) from broiler chickens in Chitwan, Nepal. BMC Veterinary Research, 14:113.

Tonu, N.S., Sufian, M.A., Sarker, S., Kamal, M.M., Rahman, M.H. and Hossain, M.M. (2011). Pathological study on colibacillosis in chickens and detection of Escherichia coli by PCR. Bangladesh Journal of Veterinary Medicine, 9: 1725.

Zanatta, G.F. et al., (2004). Suscetibilidade de amostras de Escherichia coli de origem aviária a antimicrobianos. Arquivos do Instituto Biológico, 71: p.283-286.

\section{How to cite this article:}

Chhabra, Daljeet, R. Gangil, R. Sikrodia, S. Audarya and R. Sharda. 2020. Multidrug Resistant E. coli Isolated from Kadaknath Poultry Bird. Int.J.Curr.Microbiol.App.Sci. 9(02): 1-5. doi: https://doi.org/10.20546/ijcmas.2020.902.001 